\title{
Negotiating Spaces: Latino Theater in Chicago
}

\section{José Castro Urioste}

In recent decades, due to a steady flow of immigrants from Mexico, Central and South America, and the Caribbean, Chicago has become one of the U.S. cities with the largest and most diverse Latino populations. This process of immigration has been instrumental in the development of various Latino cultural activities that both utilize the infrastructure already in existence - museums, radio and newspapers, festivals, art galleries - and create other new cultural spaces. Some examples of the latter are the Mexican Fine Arts Museum, the Latino Film Festival - whose latest edition was organized by the recently founded International Latino Cultural Center of Chicago - and the rise of Latino literary figures such as Ana Castillo, Sandra Cisneros, and Luis Rodriguez, whose books have been published in the mainstream press. This process implies a double volition: on the one hand, the desire to build a location within the new space - Chicago - and contribute to its transformations; and on the other hand, the need to establish a "mark" - a Latino thing - that is not homogeneous, but rather expresses different meanings according to the origin of the group and its relationship with the new space.

Latino theater in Chicago has developed within this context. Analyzing it implies an understanding of its double intention. Latino theater expresses a specific ethnic component clearly related to the Latin American theater tradition. But it is also incorporated into the current theatrical movement taking place in Chicago. In this sense, my purpose is to propose a hypothesis about recent Latino plays that have been produced in Chicago. As a hypothesis, it leaves several questions open. I have observed that the main characteristic of the latest performances by the Latino theater groups of Chicago is the portrayal of a self whose voice is denied. At the same time, this self insists on being heard in order to demonstrate his/her existence. This type of representation might be related to the place that Latino theater 
has within the greater context of Chicago theater, as a voice that is ignored (or limited to the Latino stereotype) but that demands a place (and therefore an existence) in Chicago's theatrical development. ${ }^{1}$ In order to support this hypothesis, I will analyze the latest performances of Teatro Vista, the Aguijón Theater Company, Luna Players Ensemble, and Grupo Cuerda Floja. ${ }^{2}$ In some cases - especially when I refer to Teatro Vista and the Aguijón Theater Company-I will not only analyze their latest productions, but also delineate the trajectory of the groups, as this, too, supports the hypothesis of a double cultural volition in Latino theater. ${ }^{3}$

\section{Teatro Vista}

In 1989, Henry Godinez and Edward Torres, after working together on a play in Chicago, decided to found Teatro Vista. What motivated them to create Teatro Vista was the fact that Latino actors were only called on to play stereotypical roles. In addition, one of Teatro Vista's initial goals was to develop a bridge with both Latino and non-Latino audiences. Behind this can be seen the double cultural volition of this group and its need to play a role not only within and for the Hispanic community, but also outside of it, within the greater Chicago theatrical context.

This double relationship has characterized Teatro Vista's trajectory. In fact, the locations of the spaces chosen for its theatrical performances reflect its desire to make a cultural "mark." 4 In January of 1991, for example, they produced an English version of Hugo Salcedo's The Crossing - its premiere in the United States - at the Mexican Fine Arts Museum. This play, dealing with the deaths of 18 undocumented Mexican workers, was acclaimed by the Pilsen audience, the most important Mexican-American community in the Chicago area. In October of the same year, Teatro Vista produced Broken Eggs by Eduardo Machado, a tragi-comedy about a Cuban-American family after Fidel Castro's revolution. This time, the performances took place in the Rogers Park community, on Chicago's North Side, an area where there is a considerable Cuban-American and Caribbean population. It is clear that the choice of the locations where these plays were produced expresses Teatro Vista's desire to address a specific audience - the Latino community — and to play a role within this community.

As a part of its double cultural volition, Teatro Vista considers it necessary to gain access to and address other sectors of Chicago as well. In this sense, on several occasions Teatro Vista has collaborated with mainstream theaters. For example, in 1998, they worked with the Steppenwolf 
Theatre's Arts Education Program on the play The Boiler Room. They also participated in the Goodman Theatre's productions of The Pain of the Macho (1994) and José Rivera's Cloud Tectonics (1995). Henry Godinez and Edward Torres' work in Luis Valdez's Zoot Suit, produced in June 2000 at the Goodman Theatre, deserves special mention. Godinez was the director and Torres played the role of Joey Castro in one of the Goodman Theatre's few mainstage productions of a Latino play. As is well known, both Valdez and his play have become icons of the Latino theater movement in the United States. Zoot Suit began its popularity in 1979 in Los Angeles, was produced on Broadway, and later was adapted to a film, in which a young Edward James Olmos played the role of El Pachuco. Despite the unquestionable success of the play in other cities of the country, Chicago waited twenty years to stage it. This long wait for Valdez's play reflects both how Latino theater has been denied a voice in Chicago and how it is now an emerging voice, demanding the attention of the entire community. Godinez's impeccable direction will most definitely stimulate more attention to the Latino voice.

The selection of locations for Teatro Vista's performances elaborates a complex net of relationships. In fact, Teatro Vista is connected with two circuits of relationships - the one that might be called mainstream and the Latino - and between them there is no link that might be defined under the dichotomy center-margin. From the perspective of the Latino self, both circuits are spaces in which it is necessary to be recognized and in which it is necessary to interact. Thus, the notion of center-margin disappears, and the Latino self becomes one that is able to articulate more than one space and to identify with both of them.

Teatro Vista's latest production was Jamie Pachino's Aurora 's Motive, directed by Edward Torres in 1999. The play takes place in Spain during the late $19^{\text {th }}$ and early $20^{\text {th }}$ centuries and narrates Aurora Rodriguez's true story. Aurora, who believes in a new society, faces repressive male rules. Her goal is to give birth to a girl and educate her as a leader. An ad for a "donor" father is successful and she finally gets pregnant. In this sense, Aurora transgresses all of society's rules and confronts the male roles that symbolize the power oppressing women: she abandons her father and gets pregnant without the need for a husband. All of this makes her a symbol of rebellion in the specific historical context in which the play takes place.

However, there is a paradox in the protagonist of the play. Aurora's concern for her daughter Hidegart's education compels her to devise repressive rules for her own daughter. She, as mother, becomes the castrator, just as the 
male figures in her youth were for her. In this sense, the play expresses that the elaboration of a repressive order is not exclusive to one gender.

Aurora's Motive may also be interpreted as a story of suppressed voices that fight for attention. Aurora, as a young woman, has the right to speak in private spaces, but not in public ones. From the perspective of the repressive male, Aurora's voice - despite her knowledge — should be limited to being a decoration in the home and men may hear it only to entertain themselves. Aurora does not accept this limitation and fights for women's voices to be heard in public spaces as well. She believes that being listened to by society is a way for women to achieve a full existence.

Hildegart's case differs from Aurora's. She becomes a leader as a teenager and her voice - through written and oral texts - is received by many. However, she begins to speak about her feelings and to express different ideas than her mother. As a consequence, Hildegart is censured by Aurora. And denying her daughter's capacity to speak also denies her daughter's full existence.

\section{Aguijón Theater Company of Chicago}

In 1989, Aguijón Theater Company of Chicago was founded by Rosario Vargas, a Colombian actress and director. From 1991 to 1999, it was located at Harry Truman College, in the heart of Uptown Chicago, but the company also produced plays that were performed in several other areas of the city. In October of 1999, the company moved to its own location. The Aguijón Theater's project implies the creation of a space - not only physical - for the Latino community, where theater and cultural events can take place. In this sense, Aguijón Theater's agenda includes its own productions, but also invites and participates in co-productions with other Latino groups, organizes musical recitals combined with poetry, and, on a monthly basis, invites a Latino theater expert to give a lecture and discuss his/her work with the audience.

Since its foundation, Aguijón Theater has produced plays both by Latin American writers - Carlos Fuentes, Mario Vargas Llosa, Esteban Navajas, Alberto Llerena - and adaptations from Latin American literary pieces. For example, its first production, Homenaje a Sor Juana Inés de la Cruz, was created from texts by the Mexican writer, and Kinsey Report (1991) was a monologue adapted from Rosario Castellanos' poem. These performances took place at several Chicago locations: the Mexican Fine Arts Museum, the University of Illinois at Chicago and Roosevelt University, library audito- 
riums, and cultural centers. During Aguijón Theater's first period-before they acquired their own location - the company decided to "conquer" several spaces of the city. Traveling around Chicago permitted them to become a "carrier" of Latin American playwriting for Latino and non-Latino audiences. In order to address not only a Hispanic audience, Aguijón Theater also developed bilingual performances. For example, in 1994, they produced the plays $T$ and The Border by Silvia Gonzalez S., and Mario Vargas Llosa's La Chunga was performed with simultaneous translation at the Mexican Fine Arts Museum.

In addition to these general characteristics, Aguijón Theater has been concerned with the production of plays that deal with gender issues. In 1995, they performed Griselda Gambaro's El despojamiento. The play was presented as part of the campaign against sexual abuse promoted by the AntiViolence Task Force and by the Latin Women in Action Group. Three years later, Aguijón Theater produced La Visita by Colombian Alberto Llerena, a play that deals with the topic of homophobia.

Aguijón Theater Company's latest production was Jorge Díaz's El génesis fue mañana, directed by Rosario Vargas. The play reflects a world in decomposition. Two of the characters, Custodio (Augusto Yanacopulos) and Hosanna (Rosario Vargas), have lost their social status. The other character, La Pioja (Aranxta Marti) represents the "barbaric" group, those who have historically been located on the margin. As part of her portrayal, she does not walk like a "normal" human being and often needs the help of her arms in order to move. This contrasts with Hosanna and Custodio's vertical position, as they walk or stand. The latter two characters are the ones who tell their stories, while La Pioja cannot speak and only pronounces sounds to express her feelings. Despite these dichotomous character descriptions, there is another opposition that turns out to be much more important: Hosanna and Custodio wander aimlessly throughout the play with no final destination or future. In contrast, La Pioja gets pregnant. Giving birth permits her to obtain the capacity to speak and the possibility of creating a future.

\section{Luna Players Ensemble and Grupo Cuerda Floja}

Two other groups that have been working on plays in Spanish are the Luna Players Ensemble and Grupo Cuerda Floja. In 1999, the Luna Players Ensemble produced the monologue Volver a decir el mar, written by Mexican playwright Sergio Peregrina. Both the director, Roma Díaz, and the actor, Carlos Jaime, were educated and have theatrical experience in Mexico. In 
December of 1999 the play was staged at the Asociación por Derechos Obreros, in Pilsen, and later, from February to March of 2000, at Aguijón Theater.

Volver a decir el mar narrates the story of a character who abandons social conventions and chooses a marginal lifestyle. This choice isolates the character from reality and he suffers a process of degradation. His only sustenance is the memory of a past love. The play might be understood as portraying the punishment that society imposes on those who break the rules, this punishment being the separation from the group. This same punitive action denies the self his right to speak. In other words, his voice can no longer be heard. For this reason, the character creates imaginary beings: Juanita, for example, his former lover. It is precisely this condition - the impossibility of being heard by others - that makes him a marginal self.

The other Latino theater group that has developed important performances in Chicago is Grupo Cuerda Floja. Grupo Cuerda Floja recently performed Emilio Huerta's Horas de encuentro, directed by Eduardo Von. Von, like some of the members of Luna Players Ensemble, has a Mexican theater background. He later worked as an actor and director in the U.S.

Huerta's Horas de encuentro begins when a criminal-Riego, played by Von-breaks a window and enters the home of Laura, an upper class woman. Their relationship is characterized by violence. The economy of the stage design — only a chair — emphasizes the solitary circumstances and the unlikelihood that anyone might come to Laura's aid. This, of course, makes the violence of the play more acute and more disturbing for the audience.

Horas de encuentro also reflects the transgression of rules. Riego, the criminal, is a character who under "normal circumstances" would not be heard by Laura (by the authoritarian upper class). In fact, he is depicted as having no voice in society. Horas de encuentro, however, narrates a brief moment in which all the rules are infringed. Riego invades a space that does not belong to him and, through violence, he controls it. Only under such circumstances can his voice be heard by an upper class character such as Laura (or by the ruling class in general).

But Laura also transgresses the rules. At the beginning of the play, she is gagged - she has no voice. Later, recovering her voice will grant her the capacity to negotiate with Riego and transform him into an ally. In other words, both characters have the chance to speak in a space controlled temporarily by different rules (after all, during those hours, Laura's house is not managed by her husband). This temporary situation, in which both characters can speak without any censorship, allows them to reveal their true stories 
and to decide to collaborate in a common plan. She, for example, confesses the real, repressive nature of her marriage. The play ends when the husband returns home and Riego, at Laura's behest, plans to kill him. Riego, however, realizes that while killing him might represent a benefit for Laura (for a sector of the upper class), it does not provide a way for him to maintain his right to speak. So he abandons the house, leaving the couple alone, after all the rules have been broken and the truth has been told.

It is clear that in the latest Latino theatrical productions there has been a, perhaps unconscious, preference: the representation of marginal characters. Aurora and her daughter, La Pioja in Jorge Díaz's play, the lone character in Volver a decir el mar, and Riego and Laura in Horas de encuentro all have in common the fact that their voices are not normally heard. At the same time, they demand to be heard in order to have a full existence in society. This preference reflects the situation of Latino theater in Chicago: it is a voice that has not been heard but that demands a place within both Hispanic and non-Hispanic audiences, a voice that demands a relationship with its roots, a voice that demands a role in the current Chicago theatrical context.

\section{Purdue University Calumet}

\section{Notes}

1 In academic research about Chicago theater, there is a noted absence of information about Latino theater. For example, in theses written by Gray and Sherman, Latino theater goes unmentioned in their investigations. Moreover, some summary works about U.S. Latino theater-Kanellos, Rizk's “El teatro latino," for example - do not mention the groups from Chicago. It is not my intent to criticize them; I think these works are pioneers in our field. However, there is still much to do in order to elaborate a U.S. Latino theater history.

2 One of the groups that had a significant role is the Latino Chicago Theater Company, which was founded by Dennis Zacek in 1979 at the Victoria Gardens Theater. Two years later it became an independent entity. In 1987, Latino Chicago Theater Company moved into its own location, the Firehouse, where they were intensely active. Unfortunately, the company has discontinued its productions, and for that reason is not part of this research.

3 This double cultural volition is not exclusive to Latino theater in Chicago. It might also be applied to Latino theater performances produced in other American cities. During recent decades, this double cultural volition has intensified due to the multicultural agenda. On multiculturalism and U.S. Latino theater, see Rizk, "Haciendo historia."

4 Villegas mentions that research studies on Spanish and Latin American theater do not analyze the spaces ("sala de espectáculos") where plays were produced. For Villegas, "la sala de espectáculos, en muchas ocasiones es un indicio de la clase de destinatario y de la clase de público y de los códigos estéticos" (58). 


\section{Works Cited}

Bourdieu, Pierre. Las reglas del arte. Génesis y estructura del campo literario. Trans. Thomas Kauf. Barcelona: Anagrama, 1995. Print.

Gray, Stephen. "A History of the Chicago Off-Loop Theatre Explosion: 1969 to 1989." Ph.D. Diss., Ohio State U, 1997.

Kanellos, Nicolás. "An Overview of Hispanic Theatre in the United States." Hispanic Theatre in the United States. Ed. Kanellos. Houston, Texas: Arte Público, 1984. 7-14. Print.

Mayer, John. "The Steppenwolf Theatre Company of Chicago, 1974-1982." Ph.D. Diss., U of Missouri, 1993.

Rizk, Beatriz J. "Haciendo historia: Multiculturalismo y el teatro latino en los Estados Unidos." Ollantay 1 (1993): 9-18. Print.

. "El teatro latino de Estados Unidos." Tramoya: Cuaderno de Teatro 22 (1990): 5-20. Print.

Sherman, James. "Chicago Actor's Repertory Company: Design and History." Thesis, Saint Xavier College, 1971.

Villegas, Juan. Para un modelo de historia del teatro. Irvine, CA: Gestos, 1997. Print. 